\title{
How Do Developing Countries Achieve Carbon Emission Reduction? An Examination of the Case of China and Its Replicability
}

\author{
Yixuan Fan ${ }^{1, \dagger}$, Shurui $\mathrm{Guo}^{2, *}, \dagger$, Shurong $\mathrm{Li}^{3, \dagger}$ \\ ${ }^{1}$ School of International Relationship and Diplomacy, Beijing Foreign Studies University, Beijing, China. \\ ${ }^{2}$ Beijing Normal University - Hong Kong Baptist University United International College, Zhuhai, China \\ ${ }^{3}$ College of Public Management, Inner Mongolia University, Hohhot, China \\ *Corresponding author. Email: p930032017@mail.uic.edu.cn \\ These authors contributed equally.
}

\begin{abstract}
In recent years, massive greenhouse gas emissions have greatly contributed to and exacerbated global climate change, posing a huge threat to human survival and development. However, for developing countries, global climate change could have even more serious consequences. It is likely to have negative economic effects for developing countries and face a dilemma where economic growth and carbon reduction are at odds with each other, if developing countries adopt carbon reduction policies. This essay uses China's carbon reduction policies and achievements as an example showing how a developing country could balance the economic development and carbon reduction, by analyzing Chinese experience through the aspects of government, market and technology. In terms the replicability of the China's success, our research reveals that the Chinese experience applied in other developing countries to balance the domestic development and carbon reduction is limited in Least Developed Countries but relatively high in more developed developing countries, such as countries in the group of BRICS.
\end{abstract}

Keywords: Carbon reduction, Chinese experience, Developing countries

\section{INTRODUCTION}

Climate change has become a hot topic in recent years. It is confirmed that the huge amount of greenhouse gas emitted by human beings greatly triggers and exacerbates global climate change [1], which poses a huge challenge to human survival and development. For developing countries, this consequence is more serious, because their less developed economy and society are more likely to be influenced by extreme climate events caused by climate change [2]. Therefore, figuring out the reason for excessive emissions and ways to reduce carbon emissions to mitigate climate change is of crucial importance. When thinking about why human beings emitted so much, it is widely argued that it is the overuse of material and energy when chasing economic development that created such amount of carbon emissions [3-4]. For developed countries, this process happened earlier and made themselves into modernization, while developing countries were much later than developed countries in the process of industrialization. While it is not fair to hold the latter responsible for the former's emissions history, it has to be acknowledged that developing countries also bear some responsibility. Developing countries matter more to lower global carbon emissions, considering that they account for $63 \%$ of global carbon dioxide emissions, $26 \%$ more than that of developed countries [5]. To reduce emissions, it is highly accepted that countries, no matter developed or developing ones need to decouple economic growth from carbon emissions, meaning growing economies with less carbon emissions even to zero emissions [6].

Decoupling is difficult for developing countries. First of all, the reason why developing countries emit more than developed countries is that their development is based on highly polluting technologies and high population growth [7]. Their development relied on fossil-fuel-driven and energy-intensive industry, which have dreadfully compromised the local environment [8]. Traditional kind of energy sources, such as oil, natural gas, and coal, compared with renewable energy resources, means less cost and more profitable for these countries 
[9]. When most developing countries are still struggling with poverty, hunger, health problems etc., it is comprehensible that for most developing countries economy development is prior to carbon emission reduction [10].

It is really hard for developing countries to decouple economic growth from carbon emissions in such a short period by themselves. For developed countries, it is possible to achieve decoupling because of their more developed economy and better-established industry structure [11], while for developing countries, simply decoupling means economic stagnation and a slowdown in poverty reduction due to the lack of funds to invest in clean energy or energy-efficient technologies [12]. It is widely verified that, under the circumstance that energy consumption is nearly composed of the consumption of fossil fuel, when energy consumption increases, GDP grows; when GDP grows, it tends to increase carbon dioxide emissions [13-14]. Therefore, impetuous adoption of carbon reduction policies is likely to bring negative economic effects, and developing countries are in a dilemma where economic growth is mutually exclusive with reduction of carbon emission.

Dating back to 1987, UN has brought up the concept of sustainable development and asked its member countries to make rational use of natural resources [15]. In 2015, the Agenda 2030 required the UN member countries to "take urgent action to combat climate change and its impacts" [16]. Until the Signing of the Paris Agreement in 2015, the global governance of climate change has made great progress. The enactment of the Paris Agreement has changed the situation in the era of the Kyoto Protocol, when the trade-offs between economy and environment are not a priority for most developing countries. The emission commitments of Paris Agreement pushed countries to reduce carbon emissions [17]. Under this circumstance, some scholars argued that developing countries must combine development and emission reduction to achieve sustainable development (SD) [18]. For example, Ayers and Huq [19] inferred that if countries can achieve a synergy between carbon emissions and economic growth, SD could be implemented. Hardee and Mutunga [20] also wrote that climate change policies may impede sustainable development if they are not aligned with the common interests of national development plans. In this way, China is an example which is worth researching, as a developing country who controls carbon successfully.

China is a typical developing country who has been trapped in the dilemma of reducing emissions and developing economy. On the one hand, China is such a big contributor for global carbon emissions that the success of controlling global warming is nearly tied with China slowing down its emissions [21]. On the other hand, China has developed fast partly owing to the use of fossil fuel. Though China's economy continues to grow, having become the second largest in the world [22], Chinese government is in dilemma that economic growth leads to energy consumption and carbon emissions, whiles adopting energy-saving policies adversely affects economic prosperity [14].

This development mode started to change after the promulgation of the $2030 \mathrm{UN}$ agenda, which will provide new motivation and mechanism to reduce carbon emissions [23]. In June 2015, China published its Nationally Determined Contribution (NDC) under the United Nations Framework Convention on Climate Change, reaffirming its commitment to reduce the carbon intensity (per unit of energy consumption) by 60 to 65 percent from 2005 levels by 2030 [24]. In September 2020, president Xi declared that China aims to peak its carbon dioxide emissions by 2030 and strive to achieve carbon neutrality by 2060 [25]. To achieve these ambitious commitments, China started to reform and actually did get great achievement. For example, in 2019, carbon intensity dropped 48.1 percent from 2005, reversing the rapid growth of carbon dioxide emissions [26].

Facing the great progress made by China, academia becomes interested in the success of China on carbon reduction. Some scholars have discussed on the topic at the international level. For example, some take interests in the impact of Chinese successful emission reduction, including the possible transfer of power of leadership in climate change, especially featuring the competition between China and the US [27]. Viola et al. [28] also pay attention to the history of China gradually entering the inner circle of climate governance. Meanwhile, there is some discussion on the topic at the domestic level. For example, Wu et al. [29] utilize quantitative methods to compare differences of development between provinces of China, how well or badly these provinces do in reducing carbon emissions; Hu et al. explore how useful Chinese government public spending is on carbon emissions [30]; and Long et al. probe into the relationship among renewable energy consumption, commercial trade and carbon emissions by data analysis [31].

Then, can China become a replicable example for other developing countries who struggle with sustainable development? After all, it is interesting to see China as a developing country achieving it that coal consumption accounted for $10.8 \%$ less of total energy consumption than in 2012, while GDP achieved an average annual growth of 7\% from 2012 to 2019 . Therefore, a general analysis of the possibility of coping Chinese experience is necessary. This essay analyses Chinese experience through aspects of government, market and technology, to give readers some understanding of the reason for Chinese success. The following article will start with a detailed analysis unravelling the success of China on balancing the trade-off between economic growth and carbon reduction, followed by a discussion on how 
Chinese experience can be applied to other developing countries.

\section{CHINESE EXPERIENCE ON CARBON REDUCTION}

\subsection{Policy Support from Chinese Government}

First of all, the government support is key to China's success, especially its leadership, funding for encouraging carbon reduction and policies for supporting a lively carbon market.

\subsubsection{Government Leadership}

Brandt [32] once pointed out in his book, that the most critical driver of Chinese reform is the determination of senior leaders to continue to deepen the reform process. When it comes to environment revolution the situation is similar as well. The leadership of Chinese government, especially the central government, promotes the process of reducing emissions to a great extent. There are three main points. Firstly, it is the central government that provides the general direction for the whole process. China has changed its previous policy of pursuing separate national strategies for ecological conservation and economic development to a policy integrating the two. It was shown by the statement of President $\mathrm{Hu}$ in the 18th CPC National Congress, which highly emphasised that China should give high priority to ecological progress, and more importantly, integrate it into all aspects and the whole process of economic, political, cultural, and social development [33]. Here, Chinese government has emphasised that China would change the old development mode into sustainable development, balancing the relationship between development and emission reduction. This lays the foundation of sustainable development for further organisation and management.

Secondly, the Chinese government played a crucial role in managing and coordinating the national plan of carbon reduction. As Afrifa et al. [34] pointed out sometimes good governance will play an important role in carbon reduction. China did well in this aspect. For example, in the 13th Five-Year Plan published by State Council, the government makes the master plan, sets standards for discharge of pollutants and for emission of greenhouse gases in every industry, and makes general plans of emissions reductions and energy savings [35]. It is the central government that coordinates all the activities of the nation as in a chess game. Due to allround considerations and arrangements, the reforms in all industries were carried out in good order under the general plan and resulted in China's success in reducing carbon emissions.

Additionally, national planning does not equal to unifying standards and methods among all regions. When the centre government makes suggestions, the local government needs to adjust measures to local conditions. Eastern and western provinces in China have different measures to reduce emissions, because of their uneven economic development. For example, western provinces have ecological protection compensation mechanism to form financial support relationships with eastern governments which have adequate fund for transferring into sustainable development. Because most western regions are abundant of natural resources but their economies are quite undeveloped, these government in western provinces have special methods to get aids to fulfill the emission reduction and development targets assigned by the central government. Through ecological protection compensation mechanism, these governments have already established cooperation on ecocompensation with the eastern regions which have high energy consumption rate but lack natural resources [36]. This kind of special horizontal ecological protection compensation mechanism released pressure of poor areas, which need money to develop their economy as well as protect environment, with sufficient funds from rich cities. In this way, the support of Chinese government helps solve the fund shortage problem in less developed areas, so that China can reduce such carbon emissions.

\subsubsection{Governments Support through Funding}

In fact, addition to the role of general leadership, the economic support of the government is more specific to facilitate reducing carbon emissions [30]. Local governments supply fund subsidy for individuals and companies to help promoting new energy. For companies, Chinese government have provided funds for vehicle companies to compensate for the loss of research and development of new energy vehicles. Meanwhile, individuals who buy new energy cars will receive compensations from local government. For example, in Tianjin, customers will be compensated with a 2,000yuan voucher for charging their electric cars [37]. What local governments do helps manufacturers reduce R\&D costs, lower product prices, and guide consumers to buy energy-saving products. Consumers' new consumption preferences will indirectly guide manufacturers to produce energy-saving and emission reduction products they like, forming a closed loop of mutual promotion.

\subsubsection{Combining Government Supportive Policies with Carbon Market}

To coordinate and allocate China's domestic resources and personnel for carbon reduction, Chinese government not only proposed supportive policies for the carbon market, but also established distinctive measures for localization and implementation of Clean Development Mechanism. 
Carbon market is the most effective economic solution for balancing the economic growth and carbon reduction, and mitigating the externalities of carbon emissions [38]. Carbon price of carbon quote, is the most significant component in carbon market, which can measure the effectiveness and efficiency of carbon reduction in carbon trade. Theoretically, to stimulate and promote the carbon reduction in certain carbon market, high carbon price is required. However, with low carbon price, China still has a relatively successful performance on carbon reduction under the guidance of administrative and legal measurements from Chinese central government. A few years after the declaration of National Development and Reform Commission, on the start of Chinese carbon trade, Chinese central government established a few domestic pilot carbon markets and proposed some measurements as guidance, proved to be relatively successful.

By December 31th, 2020, Chinese central government has set up eight domestic pilot carbon markets, which have created the quota spot turnover of 445 million tons and turnover of 10,431 million yuan at the transaction price of 23.5 yuan / ton [38]. Among these eight pilots carbon markets, Beijing market is regarded as the most successful example under the guidance of China (Beijing) Free Trade Pilot Zone Overall Plan. Through open market operation and management and strict distribution of carbon quota, the positive relationship between supply and demand sides are created, the carbon price of Beijing Pilot carbon market is maintained at a level of around 50 to 70 yuan/ton. Thus, with the stable expectation of carbon quota and the increasing confidence of actors in carbon market, the carbon intensity is decreased. The cumulative carbon intensity of Key Carbon Units in Beijing decreased by $16.5 \%$ from 2016 to 2019 under the instruction of government [38]. This reveals that the carbon markets, especially the markets under the construction of state government, have the effective impacts on controlling the Greenhouse gases, such as $\mathrm{CO} 2$.

Except for the domestic pilot carbon markets, Chinese state financial administrations also support the establishment and development of green financial services system and international green financial centers to promote the implementation of green development institutions, which emphasize the sustainable development and the goal of carbon neutrality. Later, in December 31th, 2020, the Ministry of Ecology and Environment established the Measures for the Administration of Carbon Emission Trading (Trial Implementation) (Ministry Decree No. 19) to complete the legislation towards carbon trading and carbon markets to maintain the carbon market transaction orders [39]. The legislation further guarantees the safety and transparency of the carbon trading market and stimulates the carbon reduction process.
Besides the regulation towards carbon market, Chinese government also established the Interim Measures for the Operation and Management of Clean Development Mechanism Projects to promote the domestic implementation of Clean Development Mechanism (CDM), a mechanism for mutual cooperation between developed and developing countries in the field of global carbon reduction [40]. Though this mechanism, Chinese government specified detailed information of domestic CDM implementation, such as the major area of Chinese CDM projects and the responsibility of each management and implementation institution, to create favorable market environment and attract more domestic and foreign investment for construction of CDM projects. By considering the characteristics of domestic Chinese market and environment, this measure brings opportunities for China's green growth and green economy.

\subsection{Supply and Demand Sides of Chinese Carbon Market}

As the actors of demand and supply sides of carbon market, the domestic enterprises and individual consumers in carbon market also make contribution to the carbon reduction in China, in additional to the government.

For Chinese enterprises, especially the enterprises in energy and carbon trade sectors, on the one hand, they play an essential role in providing domestic capital and attracting foreign direct investment. To provide sufficient capital for domestic carbon market, it is vital to balance the green bonds and green equity. Using one of the most famous Chinese companies in carbon trade, Beijing Green Exchange Co. LTD [38], as an example. This company set up Carbon Neutral Equity Investment Fund and Climate Equity Investment Fund to maintain the balance of green bonds and green equality while foster the carbon neutral business model at the same time. What's more, under the safe and stable market environment provided by Chinese government, the payback period and investment return for investments in China is of high certainty, which is the core attraction for foreign direct investment in carbon market, for the foreign investors. This means investors can obtain substantial return in a relatively acceptable payback period. For instance, the investment for projects in cement, iron and steel sectors in China, has the payback periods of only two to three years, much shorter than other developing countries around the world. Thus, according to Liu's investigation, seventy percent of foreign enterprises show strong desires to invest in the low-carbon technology and projects in these three sectors in 2016 in China [41]

On the other hand, enterprises influence the domestic supply and demand chain through their investments, services as well as products. With the development of 
carbon trade and carbon economy, more and more enterprises start to provide services and products related to carbon reductions. Still using the Beijing Green Exchange Co. LTD as an example, it provides carbon neutral services not only to the market actors, such as energy companies and individual consumers, but also offers consultation to administrative departments. The enterprise has already assisted Chinese government to establish hundreds of Chinese Certified Emission Reduction (CCER) projects, which are essential for the Chinese domestic carbon reduction [42]. In 2016, cooperating with Ant Financial Services Co, their Ant Forest Project has accumulated 550 million users and has already planted two hundred million of trees in the world, which is proved to contribute around 12 million tons carbon reductions around the world [38].

On behalf of the demand sides, the consumption options of individual consumers largely affect the further development and variation of market. In other words, the consumption behaviors and preference of individual consumers in carbon market are the core driver to the industrial and market transformation. From the successful experience of Ant Forest Project, which is illustrated before. It is obvious that Chinese successful experience on carbon reduction largely related to the adjustment of energy and industrial structures, which is driven by the transformation from the green investment to green consumptions [43]. Huge amount of green consumer groups will encourage the development of green production, green consumption and green circulations thus promoting the process of green development.

\subsection{Strong In-house Technology Development}

China is actively engaged in research and development of carbon reduction technologies, which provide lessons for other developing countries. Firstly, China has increased its research and development in carbon reduction technologies in various fields, including the power sector, industry, transport and construction sectors. For example, China has actively developed USC combustion technology, which is an advanced coal combustion technology. China now has more 1000MW units than any other nation and also has some of the most advanced coal plants with the lowest net coal consumption rate in the world [44]. Moreover, new energy vehicles play an important role in achieving the goal of Carbon Peaking and Carbon Neutrality. The new energy automobile industry is a strategic emerging industry with huge growth potential, and is a representative of the deep integration of emerging technologies and new industries. It is expected to alleviate the energy crisis, create new drivers for economic growth and drive the transformation and upgrading of the entire automobile industry. In addition to this, China has made breakthroughs in research and development in energy efficient recycling technologies, zero carbon energy technologies and negative emission technologies. Secondly, as Sachs [45] points out, due to the high sunk costs, high R\&D risks and strong spillover nature of low carbon technology innovation, companies have little incentive or capacity to undertake low carbon technology innovation and application, which is often inefficient or even unsustainable [46]. In contrast, the efficiency of Chinese enterprises' low carbon technology innovation is enhanced if they use the Clean Development Mechanism. According to statistics, by the end of the first half of 2010, China's registered CDM projects were expected to reduce emissions by an average of 230 million of Carbon dioxide content per year, with average annual CER revenues of $€ 2-3$ billion [47]. Finally, Chinese universities and institutions are actively engaged in scientific research and academic studies on carbon emission reduction technologies, which have made a significant contribution to China's goal of on carbon peaking and carbon neutrality. For example, Tsinghua University has proposed a comprehensive solution for deep emission reduction by combining emission characteristics and eventually developed a key technology for deep flue gas multi-pollutant treatment. Chinese universities and institutions will deepen cooperation in the treatment business, reduce the impact of industrial and corporate emissions on the air environment, and help promote green development and high-quality development.

\section{DISCUSSION}

China shows a good example of how a developing country could balance economic growth and carbon reduction. However, there are some limitations for other developing countries to replicate the "China story". First, there are many developing countries, especially the Least Developing Countries, whose priority is fighting poverty instead of balancing poverty with sustainability. Second, other developing countries may not have a strong and capable government as China. With the absence of collective central power, they could not coordinate and integrate domestic resources to conduct projects as effective as China. This means the obstacles and inefficiency inevitably existed in the decision-making process and implementation process in developing counties, especially for countries which suffer from severe corruption, crisis of public distrust and are at the risk of downfall frequently. Third, most of the developing countries do not have enough capital to support strong inhouse R\&D. With unstable environment and inadequate mechanisms on various areas, most of developing countries don't have sufficient funds to support the development of the advanced technology on carbon reduction, nor to attract capitals and investments in their national carbon markets. Moreover, besides insufficient capital, advanced technology from developed countries is more likely to flow to those developing countries with 
technology and science basis rather than those extremely underdeveloped. Compared to most of developing countries, China has better basis of advanced technology. Thus, it easier for China to undertake the technology transformation.

But for some emerging countries with relatively vast economic scale or relatively better development, such as BRICS countries (those other than China), Chinese experience is worth referencing. Especially for those centralized countries which can allocate resources and funds at national level easier and have better risk resistance capacity, such as Brazil, China's experience might be well referenced.-

The replicability for Brazil, one of the BRICS countries, to undertake Chinese experience is relatively high on economic aspects. On the economic aspects, with similar development pattern, pathway, and context, China and Brazil have made economic miracles in the 1970s and 1980s through the pathway of revolution and opening-up. The fast economic development in these two countries is largely rely on undertaking the low-end industries from developed countries. In short-term, this strategy boosts the domestic economy. However, these polluted low-end industries are gradually revealed as the causes of environmental issues, which are harmful for the further long-term economic development. Transformation of energy consumption and industrial structure gradually become the core of the future economic sustainable development for China and Brazil. This means under the similar development economic development pattern and industrial structures, it's easy for Brazil to imitate China's experience on stable transformation and adjustment on energy consumption and industrial structures. Using the transformation on the technology as example, as China and Brazil all have relatively developed technology basis, Brazil can make references to Chinese experience of localizing and implementing the CDM projects into domestic world to obtain foreign low carbon technology transfer. In this way, Brazil can mitigate the carbon emission in certain areas and stimulate the upgrading and transformation of traditional energy enterprises.

Even though the replicability is high on economic aspects, the obstacles are still existed. Firstly, compared to China, Brazil has stuck in the economic depression for sometimes, which is caused by radical deindustrialization. This means Brazil's current domestic context is more complex due to the unstable transformation. As a result, Chinese pathway can only be a positive example for Brazil on transformation of energy consumption and industrial structure. Secondly, on the political aspects, Brazil doesn't have such collective central government to conduct and implement the topdesign nationwide. With the absence of the central power, one the one hand, it is a little bit hard for Brazil to make regulation and legislation in domestic carbon market to adjust and maintain the carbon price to promote carbon trade as effective and efficient as China. On the other hands, it is also difficult for Brazil to use administrative power to set the domestic carbon pilot areas as China did to allocate and integrate regional resources for collaborative carbon reduction. Therefore, the localized adjustment and adoption should be taken into consideration. Once Brazil finds its distinctive pathway, it can not only make contribution to its domestic development, but also can benefits the carbon reduction worldwide.

\section{CONCLUSION}

Although the obstacles existing, our research reveals that the replicability to implement Chinese experience in other developing countries to balance the domestic development and carbon reduction is limited in LDCs but relatively high in more developed developing countries. It is obvious that distinctive Chinese measures of government supports, market incentive, and technology development are vital to create peace and stable environment for carbon reductions. Once the developing countries with similar situations and conditions combine the Chinese pathway with their domestic contexts, we believe these developing countries can explore a suitable and effective way to reduce carbon emission thus making contributions to global carbon reduction in the future.

\section{REFERENCES}

[1] IPCC (2014). Climate Change 2014: Synthesis Report. Contribution of Working Groups I, II and III to the Fifth Assessment Report of the Intergovernmental Panel on Climate Change [Core Writing Team, R.K. Pachauri and L.A. Meyer (eds.)]. IPCC, Geneva, Switzerland.

[2] Funatsu, B.M., Dubreuil, V., Racapé, A., Debortoli, N.S., Nasuti, S., Le Tourneau, F.-M. (2019). Perceptions of climate and climate change by Amazonian communities. Global Environmental Change, (57), p. $101923 . \quad$ DOI: https://doi.org/10.1016/j.gloenvcha.2019.05.007.

[3] Schandl, H., Hatfield-Dodds, S., Wiedmann, T., Geschke, A., Cai, Y., West, J., Newth, D., Baynes, T., Lenzen, M., Owen, A., (2016). Decoupling global environmental pressure and economic growth: scenarios for energy use, materials use and carbon emissions. J. Clean. Prod. (132), pp45-56. DOI: https://doi.org/10.1016/j.jclepro.2015.06.100

[4] Shuai, C., Chen, X., Shen, L., Jiao, L., Wu, Y., Tan, Y., (2017). The turning points of carbon Kuznets curve: Evidences from panel and time-series data of 164 countries. J Clean Prod (162), 1031-1047. DOI: https://doi.org/10.1016/j.jclepro.2017.06.049 
[5] Center for Global Development (CDG), (2015, August 18) Developing Countries Are Responsible for 63 Percent of Current Carbon Emissions. https://www.cgdev.org/media/developingcountries-are-responsible-63-percent-currentcarbon-emissions (Accessed 13th October 2021)

[6] Deutch, J., (2017). Decoupling Economic Growth and Carbon Emissions. Joule. 1(1). 3-5. DOI: https://doi.org/10.1016/j.joule.2017.08.011

[7] Abubakar, I.R. \& Dano, U.L., (2019). Sustainable urban planning strategies for mitigating climate change in Saudi Arabia. Environ. Dev. Sustain. DOI: https://doi.org/10.1007/s10668-019-00417-1

[8] Ahmed, K., Rehman, M. U., \& Ozturk, I. (2017). What drives carbon dioxide emissions in the longrun? Evidence from selected South Asian Countries. Renewable \& Sustainable Energy Reviews, (70), 1142-1153.

DOI: https://doi.org/10.1016/j.rser.2016.12.018

[9] Zaman, R., Brudermann, T., Kumar, S., Islam, N. (2018). A multi-criteria analysis of coal-based power generation in Bangladesh. Energy Policy, (116). pp.182-192, DOI: https://doi.org/10.1016/j.enpol.2018.01.053

[10] Dong, C., Dong, X., Jiang, Q., Dong, K., Liu, G. (2018). What is the probability of achieving the carbon dioxide emission targets of the Paris Agreement? Evidence from the top ten emitters. Sci. Total Environ., (622), pp. 1294-1303, DOI: https://doi.org/10.1016/j.scitotenv.2017.12.093

[11] Wu, Y., Zhu, Q., Zhu, B., (2018). Decoupling analysis of world economic growth and $\mathrm{CO} 2$ emissions: A study comparing developed and developing countries. J. Clean. Prod. (190), 94-103. DOI: https://doi.org/10.1016/j.cyto.2018.04.027

[12] El Montasser, G., Ajmi, A.N. \& Nguyen, D.K. (2018). Carbon emissions-income relationships with structural breaks: the case of the Middle Eastern and North African countries. Environ Sci Pollut Res (25), 2869-2878. DOI: https://doiorg.ezproxy.keele.ac.uk/10.1007/s11356-017-07254

[13] Shahbaz, M., Mahalik, M. K., Shah, S. H., \& Sato, J. R. (2016). Time-varying analysis of CO2 emissions, energy consumption, and economic growth nexus: Statistical experience in next 11 countries. Energy Policy, (98), 33-48. DOI: https://doi.org/10.1016/j.enpol.2016.08.011

[14] Chang, C.-C. (2010). A multivariate causality test of carbon dioxide emissions, energy consumption and economic growth in China. Applied Energy,
87(11),

$3533-3537$.

DOI:

https://doi.org/10.1016/j.apenergy.2010.05.004

[15] United Nations. (1987). Our Common Future: Brundtland Report. https://www.un.org/en/ (Accessed 8th Oct 2021)

[16] United Nations. (2018). The Sustainable Development Goals Report 2018. https://www.un.org/en/ (Accessed 12th Oct. 2021)

[17] Wadhwa, D., Mani, M., Hussein, Z., Narayanan Gopalakrishnan, B. (2018). Paris Climate Agreement and the Global Economy. https://openknowledge.worldbank.org/handle/1098 6/29604 (Accessed 8th Oct 2021)

[18] Sanwal, M. (2015). The World's Search for Sustainable Development: A Perspective from the Global South, Delhi: Cambridge University Press, p. 161.

[19] Ayers, J.M., Huq, S. (2009). The value of linking mitigation and adaptation: a case study of Bangladesh. Environ. Manag., 43 (5), pp. 753764, DOI: https://doi.org/10.1007/s00267-0089223-2

[20] Hardee, K., Mutunga, C. (2010). Strengthening the link between climate change adaptation and national development plans: lessons from the case of population in National Adaptation Programmes of Action (NAPAs). Mitig. Adapt. Strategies Glob. Change, 15 (2), pp. 113-126, DOI: https://doi.org/10.1007/s11027-009-9208-3

[21] Our world in Data. (2020). Annual total $\mathrm{CO}_{2}$ emissions, by world region. https://ourworldindata.org/grapher/annual-coemissions-by-regio

[22] Zhang, Y., Shen, L., Shuai, C., Bian, J., Zhu, M., Tan, Y., Ye, G., (2019). How is the environmental efficiency in the process of dramatic economic development in the Chinese cities? Ecol. Indic. (98), 349-362.

DOI:

https://doi.org/10.1016/j.ecolind.2018.11.006

[23] China Council for International Co-operation on Environment and Development (CCICED). (2020). Green Transformation and Sustainable social governance.

http://www.cciced.net/zcyj/yjbg/zcyjbg/2020/2020 08/P020200916717159556000.pdf

[24] National Development and Reform Commission. (2015). Enhanced actions on climate change: China's intended nationally determined contribution. http://www4.unfecc.int/submissions/indc/Submissi on $\% 20$ Pages/submissions.aspx 
[25] National Development and Reform Commission. (2015). China has submitted its Nationally determined Contribution to climate change. https://www.ndrc.gov.cn/xwdt/xwfb/201506/t20150 630_955646.html? code $=\&$ state $=123$

[26] People's Republic of China Information Office of The State Council. (2020, December 21). China's Energy Development in the New Era. http:/www.gov.cn/zhengce/2020-

12/21/content_5571916.htm

[27] Karlsson, C., Parker, C., Hjerpe, M., \& Linnér, B., (2011). Looking for Leaders: Perceptions of Climate Change Leadership among Climate Change Negotiation Participants. Global Environmental Politics. 11(1). p89-107. DOI: https://doi.org/10.1162/GLEP_a_00044

[28] Viola, E., Franchini, M., \& Ribeiro, T. L. (2012). Climate governance in an international system under conservative hegemony: the role of major powers. Revista Brasileira de Política Internacional, 55(spe), 9-29. DOI: https://doi.org/10.1590/S003473292012000300002

[29] Wu, Y., Tam, V. W., Shuai, C., Shen, L., Zhang, Y., \& Liao, S. (2019). Decoupling China's economic growth from carbon emissions: Empirical studies from 30 Chinese provinces (2001-2015). The Science of the Total Environment, 656, 576-588. DOI:

https://doi.org/10.1016/j.scitotenv.2018.11.384

[30] Hu, Z. Y., Zhu, L., \& Tang, Y. W., (2014). Carbon emission reduction effect of Chinese government public expenditure: Empirical analysis based on panel simultaneous equation model. China Population Resources and Environment (10),32-40. https://kns.cnki.net/kcms/detail/detail.aspx?FileNa $\mathrm{me}=$ ZGRZ201410006\&DbName $=$ CJFQ2014

[31] Long, X., Naminse, E. Y., Du, J., \& Zhuang, J. (2015). Nonrenewable energy, renewable energy, carbon dioxide emissions and economic growth in China from 1952 to 2012. Renewable \& Sustainable Energy Reviews, 52, 680-688. DOI: https://doi.org/10.1016/j.rser.2015.07.176

[32] Brandt, L \& Rawsik, T. G., (2008). China's Great Economic Transformation. Cambridge University Press.

[33] Hu, J. T. (2012, November 18). Unswervingly advance along the path of socialism with Chinese characteristics and strive to finish building a moderately prosperous society in all respects, People's Daily.
[34] Afrifa, G. A., Tingbani, I., Yamoah, F., \& Appiah, G. (2020). Innovation input, governance and climate change: Evidence from emerging countries. Technological Forecasting and Social Change. (161). 120256.

DOI: https://doi.org/10.1016/j.techfore.2020.120256

[35] State Council. (2017, January 5). Circular of The State Council on printing and distributing the 13th Five-Year Comprehensive Work Plan for Energy Conservation and Emission Reduction. http://www.gov.cn/zhengce/content/201701/05/content_5156789.htm

[36] ECONOMIC DAILY. (2021, January 18). 14th Five-Year Plan is the Key to Achieve Carbon Peak. Retrieved from Central People's Government of the People's Republic of China: http://www.gov.cn/xinwen/202101/18/content_5580590.htm

[37] Tianjin Finance Bureau (2020, December 23). Municipal Finance bureau allocated the first batch of new energy vehicle consumption voucher subsidy funds.

http://cz.tj.gov.cn/xwdt/gzdt/202012/t20201223_51 33102.html

[38] Mei Dewen. (2021). Improve the pricing mechanism of China's carbon market to solve the dilemma between development and carbon neutrality, Yue Jiang Journal(03),44-50. doi:10.13878/j.cnki.yjxk.2021.03.002.

[39] The Ministry of Ecology and Environment. (2020). The Measures for the Administration of Carbon Emission Trading (Trial Implementation) (Ministry Decree No. 19).

[40] Shi Yucheng, Yang Rui. (2012) Improvement of government environmental responsibility in clean development mechanism), Western Law Review (05),67-72. doi:CNKI:SUN:GZCJ.0.2012-05-012.

[41] Liu, X. (2017, 6). Carbon Pricing to Accelerate the Diffusion of Low Carbon Technology in China. Institute for Global Environmental Strategies, pp. 113.

[42] John A. Sautter. (2009). THE CLEAN DEVELOPMENT MECHANISM ÏN CHINA:ASSESSING THE TENSION BETWEEN. Virginia Environmental Law Journal , 2009, Vol. 27, No. 1 (2009), pp. 91-118

[43] Energy Policy 110 (2017) 644-652

[44] Yi Hong Current situation, problems and trends in the development of China's new energy vehicle industry $[\mathrm{J}]$.Price regulation and anti-monopoly in China,2021(08):56-59. 
[45] Sachs, J.D. Keys to Climate Protection [J]. Scientific American, 2008(298): 40.

[46] Zhang Xiaodi, Luo Kun. Sustainability of Energy Conservation and Emission Reduction in China's High Energy Consumption and High Pollution Industries - A Discussion of the New Clean Development Mechanism[J]. Academic Monthly, 2008(11): $79-86$.

[47] Source: United Nations Framework Convention on Climate Change ( UNFCCC )、 United Nations Environment Programme (UNEP) 